\title{
Визначення категоріального апарату маркетинг-менеджменту
}

\begin{abstract}
Статтю присвячено ідентифікації категоріального апарату маркетинг-менеджменту. 3'ясовано, щуо роль управління маркетинговою діяльністю в сучасних умовах важко переоцінити. Це обумовлено необхідністю побудови дієвих комунікацій зі споживачами. Встановлено, що запорукою побудови ефективної та раціональної системи управління маркетинговою діяльністю є чітка ідентифікація ключових категорій у визначеній сфері. Обгрунтовано, щзо базовим поняттям маркетинг-менеджменту є власне категорія «маркетинг», до визначення змісту якої наразі існуе значна кількість підходів. На підставі аналізу існуючих підходів до трактування досліджуваного поняття запропоновано авторське тлумачення маркетингу як комплексної управлінської діяльності, спрямованої на реалізащію суспільних та корпоративних інтересів підприємства иляхом побудови дієвої системи комунікації зі стейкхолдерами суб'єкта бізнесу, насамперед зі споживачами. Розглянуто систему основних категорій у контексті маркетингменеджменту, щуо містить власне маркетинг, об'єкт впливу маркетингової діяльності (споживачі, покупці, клієнти), а також інструменти маркетингу (маркетинг-мікс). Визначено різницю між поняттями «споживач», «покупецьь» та «клієнт» $з$ позиції суб'єкта бізнесу. Реалізачія впливу на потреби споживачів, а також побудова системи комунікачії здійснюється через відповідний інструментарій маркетингу. Визначено поняття та зміст маркетинг-міксу як однієї із ключових категорій маркетинг-менеджменту. Ідентифіковано ключові компоненти маркетинг-міксу за класичним підходом 4P та за підходом 7Р. 3'ясовано, щуо основними елементами маркетинг-міксу є товар (product), иіна (price), місие (place), просування (proтотіon).
\end{abstract}

Ключові слова: маркетинг; маркетинг-менеджмент; споживач; покупецьь; маркетинг-мікс; 4 P.

Актуальність теми. Умови діяльності вітчизняних підприємств характеризуються високим рівнем складності, динамізму, невизначеності та нестабільності, що створює вагомі перешкоди у процесі забезпечення ефективного функціонування суб'єктів господарювання. Водночас загострення кризових тенденцій, пов'язаних як зі стадією економічного циклу, так і зі світовою пандемією, поставило перед значною кількістю українських підприємств питання не тільки забезпечення ефективності функціонування, але й виживання у сучасних економічних реаліях. Особливо гостро ця проблема постала для малих та середніх підприємств, що ведуть діяльність у сфері послуг. Обмеження звичних механізмів функціонування у сукупності зі зниженням платоспроможного попиту наголошує на аспектах взаємодії зі споживачами, зокрема залучення нових споживачів та принаймні утримання існуючої клієнтської бази. Важливим та дієвим інструментом забезпечення раціональності такої взаємодії $є$ маркетинг як сполучна ланка між підприємством-постачальником та споживачем. Тому теоретичне, методичне та прикладне забезпечення організації маркетингової діяльності підприємства є важливим науковим завданням, одним із головних компонентів якого, вважаємо, є ідентифікація ключових понять у системі управління маркетингом.

Аналіз останніх досліджень та публікацій, на які спираються автори. Значення та роль маркетингу в забезпеченні ефективного функціонування суб'єктів господарювання обумовлюють вагомий науковий інтерес до досліджуваної тематики. Серед зарубіжних дослідників маркетингу слід виокремити Ф.Бахмана, М.Блата, Ю.Вацуліка, С.Гоі, К.Келлера, Ф.Котлера, К.Теллера, А.Фло та інших. Вітчизняні дослідники маркетингу представлені такими науковцями, як I.М. Ананко, Г.М. Гузенко, Т.Ш. Дашевська, В.О. Іваненко, О.М. Лукан, О.В. Олійник, І.І. Павленко, В.Ткаченко, В.Г. Шинкаренко, Л.Й. Юрківська та іншими.

Ідентифікації змісту поняття «маркетинг» присвячено дослідження О.М. Лукан [3], у якому автор на основі аналізу наукової літератури виокремлює п’ять ключових підходів до трактування сутності досліджуваної категорії, а також наголошує на необхідності розмежування понять «маркетинг» та «збут». Грунтовне дослідження підходів до визначення категорії «маркетинг» проводять також I.I. Павленко та Т.Ш. Дашевська [5], які вирізняють вісім напрямів тлумачення аналізованого поняття. В.О. Іваненко та Л.Й. Юрківська [2] визначають сутність маркетингу та особливості організації маркетингової діяльності підприємств-виробників продовольчих товарів. Дослідження А.Баімбетової [9] присвячено визначенню ролі маркетингу в управлінні діяльністю підприємства, принципів маркетингменеджменту та основних його інструментів. Теоретико-методичні засади управління маркетинговою діяльністю розглядають Г.М. Гузенко [1] та В.Ткаченко [15]. Особливості реалізації маркетингового 
потенціалу як сукупності можливостей підприємства у сфері маркетингу визначено у роботі О.В. Олійник та В.О. Іваненко [4]. Дослідженню сутності та розмежуванню понять «споживач», «покупець» та «клієнт» присвячено роботу В.Г. Шинкаренко та I.М. Ананко [7].

Роботи Ф.Бахмана та Ю.Вацуліка [8], С.Гоі [13] сконцентровані на ідентифікації і визначенні особливостей використання маркетинг-міксу. Дослідження маркетингового інструментарію, зокрема у сфері роздрібної торгівлі, здійснено у роботі М.Блата, К.Теллера та А.Фло [11]. У статті проведено ретельний аналіз впливу інструментів маркетинг-міксу на активність та поведінку постійних покупців у сфері роздрібної торгівлі на основі дослідження даних з 41 країни. Найбільш комплексним дослідженням є робота Ф.Котлера та К.Келлера [14], що визначає особливості організації управління маркетинговою діяльністю підприємства.

Зазначаючи про вагомий науковий внесок до формування теорії управління маркетинговою діяльністю (маркетинг-менеджменту), маємо зауважити, що окремі питання, пов'язані з ідентифікацією ключових понять у цій сфері, залишаються дискусійними, а отже, потребують додаткових досліджень.

Метою статті є систематизація та визначення ключових понять у сфері маркетинг-менеджменту.

Викладення основного матеріалу. Забезпечення ефективності управління будь-якою функціональною сферою суб'єкта господарювання безумовно передбачає формування чіткого розуміння сутності явищ та процесів, що складають об'єкт управління. Тому забезпечення раціонального та ефективного управління маркетинговою діяльністю підприємства (маркетинг-менеджменту) передбачає чітку ідентифікацію ключових понять, що формують базис управлінських процесів, тобто відповідного категоріального апарату.

Безумовною основою категоріального апарату маркетинг-менеджменту $\epsilon$ власне поняття «маркетингу». Варто зауважити, що незважаючи на високий рівень наукового інтересу до вказаної сфери, поняття «маркетингу» залишається дискусійним та по-різному тлумачиться науковцями. Зокрема О.М. Лукан у своєму дослідженні визначає, що поняття «маркетингу» нерідко ототожнюється із поняттям «збуту підприємства» [3, с. 175], створюючи в такий спосіб додаткові перешкоди для розуміння досліджуваної категорії.

Одним із базових підходів до визначення поняття «маркетинг»є тлумачення, що запропоноване Американською асоціацією маркетингу. Згідно з цим підходом, маркетинг - діяльність, сукупність інституцій та процесів для створення, спілкування, доставки та обміну пропозиціями, що мають цінність для покупців, клієнтів, партнерів і суспільства в цілому [12]. Такого визначення дотримуються і дослідники Ф.Котлер та К.Келлер, посилаючись у своїй роботі на Американську асоціацію маркетингу й водночас зауважуючи, що маркетинг спрямований на ідентифікацію та задоволення людських i суспільних потреб [14, с. 27].

На підставі проведеного грунтовного дослідження, О.М. Лукан зазначає, що в цілому маркетинг розглядається як філософія, як система управління господарською діяльністю підприємства, як соціальноуправлінський процес, як наука та як специфічний вид підприємницької діяльності [3, с. 174-175]. Узагальнюючи результати досліджень, автор визначає зміст маркетингової діяльності таким чином: «маркетингова діяльність - це сукупність дій, спрямованих на управління виробничо-збутовою діяльністю підприємства, шляхом вивчення кон'юнктурних змін на ринку та максимального задоволення споживчого попиту» [3, с. 179]. Натомість I.І. Павленко та Т.Ш. Дашевська виокремлюють вісім типів поняття «маркетинг», а саме маркетинг як вид діяльності, як процес, як філософія, як вид управління, як інструмент, як форма обміну, як війна, де конкуренти - вороги, та як складне комплексне поняття [5, с.93]. У підсумку проведеного аналізу вченими сформульовано визначення: «маркетинг - це багатогранне філософсько-практичне поняття, інструмент конкуренції, який тісно пов'язаний із людською діяльністю та процесами управління організації, націленими на обмін організації зі споживачем та на вибір споживача на користь організації» [5, с. 94]. Баімбетова А. стверджує, що основний вплив маркетингу на підприємстві передбачає координацію управлінських рішень у сфері ринкового попиту, ціноутворення, продукту, комунікації та політики обслуговування для досягнення місії та успіху організації [9, с. 1322]. На інноваційній складовій маркетингу акцентують увагу В.О. Іваненко та Л.Й. Юрківська, формулюючи поняття «маркетингової діяльності» таким чином: «маркетингова діяльність - це цілеспрямований інноваційний процес, який направлений на створення та просування товарів і послуг на основі здійснених досліджень ринку» [2, с. 69].

Таким чином, зазначимо, що складний та комплексний характер маркетингу обумовлює значне різноманіття підходів до його тлумачення, а отже й певну дискусійність сприйняття. Вважаємо, що для визначення змістового наповнення поняття «маркетинг», доцільно розглянути його крізь призму основних завдань.

На думку О.В. Олійник та В.О. Іваненко, одним із ключових завдань маркетингової діяльності підприємства є розширення ринкової частки підприємства [4, с. 100]. Вважаємо, що основним завданням маркетингу є забезпечення впізнаваності та формування бажаного іміджу підприємства серед усіх зацікавлених осіб (стейкхолдерів). Зрозуміло, що основний маркетинговий вплив має бути спрямовано на покупця / споживача, проте у своїй діяльності підприємство, крім споживачів, взаємодіє також зі значною 
кількістю контрагентів, зокрема постачальниками та партнерами, а також із різними соціальними групами. Відтак ефективна взаємодія із усіма стейкхолдерами базується на формуванні дієвої системи комунікацій, що і визначає завдання маркетингу. Побудована система ділових комунікацій сприяє максимально ефективному досягненню цілей підприємства та реалізації його місії в цілому. Отже, з урахуванням розглянутих визначень та авторського бачення змісту й завдань маркетингу на підприємстві вважаємо за доцільне запропонувати таке його тлумачення: маркетинг - це комплексна управлінська діяльність, спрямована на реалізацію суспільних та корпоративних інтересів підприємства шляхом побудови дієвої системи комунікації зі стейкхолдерами суб’єкта бізнесу, насамперед зі споживачами.

Маркетинг є базовим поняттям, що визначає систему маркетинг-менеджменту, тобто управління маркетинговою діяльністю підприємства. Управління в цілому - це процес цілеспрямованого впливу суб'єкта управління (керуючої підсистеми) на об’єкт управління (керовану підсистему) 3 метою досягнення бажаного його стану та реалізації цілей. На думку Г.М. Гузенко, «управління маркетингом це аналіз, планування, втілення у життя і контроль над проведенням заходів, розрахованих на встановлення, зміцнення і підтримку вигідних обмінів із цільовими покупцями заради досягнення певних завдань організації, зокрема таких, як отримання прибутку, зростання обсягу збуту, збільшення частки ринку» [1, с. 228]. Згідно з іншим підходом, управління маркетингом - це практичне впровадження уважно продуманої інтегрованої політики компанії на ринку, що включає організацію, аналіз, планування, імплементацію заходів, спрямованих на досягнення визначених цілей підприємства на ринку, та контроль [15, с. 209]. Зважаючи на зазначене вважаємо, що маркетинг-менеджмент або управління маркетингом доцільно визначати як цілеспрямований вплив суб'єктів управління на систему маркетингу на підприємстві з метою реалізації цілей розвитку суб’єкта господарювання.

Управління маркетинговою діяльністю є складним комплексним процесом, що зі свого боку передбачає ідентифікацію основних категорій задля ефективної та раціональної його організації. Авторський погляд на систему ключових категорій у контексті маркетинг-менеджменту наведено на рисунку 1.

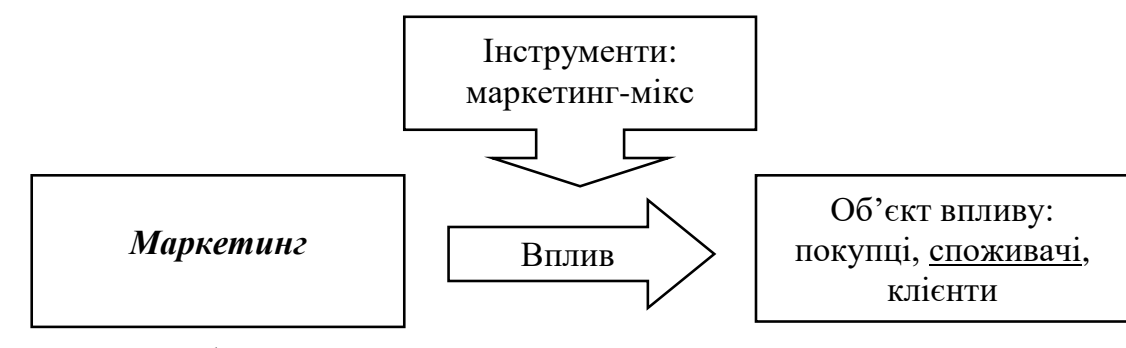

Джерело: розроблено авторами

Рис. 1. Система категорій у контексті маркетинг-менеджменту

Отже, відповідно до рисунку 1, ідентифікуємо ключові категорії, визначення яких обумовлене необхідністю раціональної організації маркетингової діяльності підприємства. По-перше, власне маркетинг, сутність якого було розглянуто вище. Згідно із запропонованим визначенням, маркетингова діяльність спрямована на формування дієвої системи комунікацій з усіма стейкхолдерами, проте первинним та найбільш вагомим об'єктом впливу є споживачі та покупці підприємства. Досить часто у економічній літературі ці поняття ототожнюються, водночас вважаємо, що такий підхід не забезпечує комплексного розуміння зазначених категорій. Покупцями 3 точки зору підприємства $є$ фізичні та юридичні особи, які беруть участь в обмінних операціях, тобто обмінюють товари та послуги, пропоновані підприємством, на гроші (здійснюють оплату товару або послуг). Причому варто зауважити, що покупець 3 точки зору конкретного суб'єкта господарювання не завжди є споживачем, адже мотиви купівлі можуть бути різними. Зокрема, якщо йдеться про В2В сегмент ринку (business to business), то покупець може купувати товари та послуги з метою подальшого їх перепродажу (яскравим прикладом $\epsilon$ торговельні мережі, туристичні агенти тощо). Споживачі ж безпосередньо використовують (власне споживають) товари та послуги, причому не обов'язково купуючи їх (наприклад, отримуючи через посередників). Крім того, зазвичай під поняттям «споживач» розуміють лише фізичних осіб, у той час як юридичні особи належать до категорії покупців. Зокрема, В.Г. Шинкаренко та І.М. Ананко на основі дослідження думок вітчизняних та зарубіжних вчених зауважують, що «доцільно як споживача приймати лише фізичну особу, окрему людину, яка придбаває товар чи послугу для задоволення особистих потреб, не пов'язаних 3 отриманням прибутків чи виконанням службових обов'язків» [7, с. 124]. Відповідний підхід закріплено також і на законодавчому рівні. Так, відповідно до ст. 1 Закону України «Про захист прав споживачів», визначено: «споживач - фізична особа, яка придбаває, замовляє, використовує або має намір придбати чи замовити продукцію для особистих потреб, безпосередньо не пов'язаних 3 підприємницькою діяльністю або виконанням обов’язків найманого працівника» [6]. 
Таким чином, ключовими критеріями для розмежування покупців та споживачів є, по-перше, юридичний статус (до споживачів належать лише фізичні особи, у той час як покупці можуть бути представлені як фізичними, так і юридичними особами), по-друге, момент споживання товару чи послуги (покупець не обов'язково безпосередньо використовує отриманий продукт). 3 точки зору маркетингменеджменту розуміння цих відмінностей $\epsilon$ важливим, адже стимулювання продажів передбачає насамперед формування мотивів у споживачів, у той час як рушійною силою для покупців може бути виключно економічний інтерес (наприклад, для покупців, що не здійснюють безпосереднє споживання, а використовують товари / послуги для подальшого перепродажу, основну роль будуть відігравати ціна та можливості подальшого збуту). Формування цілеспрямованих впливів на мотиви споживачів або інтереси покупців формує основу ефективних маркетингових комунікацій підприємства.

Досить поширеним у використанні на сьогодні $є$ також категорія «клієнт», яка є суміжною 3 вже розглянутими поняттями. На думку В.Г. Шинкаренко та I.М. Ананко, «клієнтом доцільно вважати будьяку фізичну чи юридичну особу, яка користується послугами іншої фізичної чи юридичної особи на умовах попередньої угоди між ними, що характеризується певною тривалістю та є обов'язковою для виконання обома сторонами» [7, с. 127]. 3 огляду на зазначене, вбачаємо, що клієнт за своєю сутністю є покупцем, який, водночас, купує товари / послуги підприємства протягом певного періоду часу. Тобто до клієнтів належать умовно «постійні» покупці (ті, що здійснюють купівлю неодноразово).

Третім важливим компонентом системи категорій у контексті маркетинг-менеджменту є інструменти маркетингу, тобто засоби, за допомогою яких підприємство впливає на своїх споживачів та покупців. Сервіс «Бізнес-словник» наводить таке визначення: «маркетингові інструменти - це техніки та матеріали, що використовуються особами, задіяними до просування товарів та послуг. Більшість суб'єктів бізнесу, що мають необхідність продавати свої товари чи послуги громадськості, широко використовують різноманітні маркетингові інструменти, такі як маркетингове дослідження та реклама 3 метою досягнення успіху» [10]. В цілому вважаємо, що під маркетинговими інструментами доцільно розуміти сукупність методів, технік та інструментів, що можуть бути використані для ідентифікації, встановлення та досягнення цілей бізнес-одиниці у сфері маркетингу.

Варто зауважити, що більшість науковців розглядає маркетингові інструменти крізь призму маркетинг-міксу (marketing mix), який ще має назву 4Р. На думку Г.М. Гузенко, маркетинг-мікс $\epsilon$ інструментарієм, за допомогою якого можна впливати на покупців, а також інших суб'єктів системи маркетингу [1, с. 230]. Маркетинг-мікс - це набір маркетингових інструментів, які використовує фірма для досягнення маркетингових цілей на цільовому ринку. Найбільш поширена у теорії та практиці концепція маркетинг-міксу (4Р) була запропонована Джеромом МакКарті та містить такі складові: продукт (product), ціна (price), місце (place) та просування (promotion) [13]. Водночас класична концепція маркетинг-міксу еволюціонувала під впливом змін зовнішнього маркетингового середовища. Зокрема М.Блат, К.Теллер та А.Фло [11, с. 115-117] виокремлюють такі компоненти маркетинг-міксу для роздрібної торгівлі: продукт, послуга (у контексті обслуговування), бренди, мотиви, комунікація, ціна, збут. На думку Ф.Котлера та К.Келлера, за сучасних умов розвитку концепція маркетинг-міксу має виглядати таким чином:

- елемент «люди» відображає внутрішній маркетинг, тобто орієнтацію усіх співробітників організації на якомога більш ефективну взаємодію зі споживачами, формування привабливого іміджу підприємства. Зазначений компонент відображає роль працівників підприємства у формуванні ефективної його діяльності;

- елемент «процеси» відображає рівень творчості, організованості та структурованості управління маркетингом на підприємстві;

- елемент «програми» характеризує усю діяльність бізнес-одиниці, спрямовану на індивідуального споживача;

- елемент «ефективність діяльності» розглядається в межах концепції холістичного маркетингу, тобто передбачає врахування як фінансових, так і нефінансових наслідків (у т. ч. екологічних, етичних, соціальних тощо) [14, с. 47-48].

На думку Ф.Бахмана та Ю.Вацуліка, класичний маркетинг-мікс доцільно доповнити такими компонентами, як фізичні властивості (товару або місця, де надається послуга - physical facilities), управління процесами (реалізація процесного підходу в управлінні - process management) та персонал (personnel) [8]. Таким чином, маркетинг-мікс набуває вигляду 7P.

Узагальнюючи наведене вище, маємо зауважити, що маркетинг-мікс є комплексом інструментів маркетингу, тобто методів, технік та інструментів, що можуть бути використані для ідентифікації, встановлення та досягнення цілей бізнес-одиниці у сфері маркетингу. Існує значна кількість підходів до визначення складу компонентів маркетинг-міксу, проте у будь-якому випадку об'єктом впливу під час застосування інструментарію маркетингу є споживачі та покупці підприємства.

Висновки та перспективи подальших досліджень. Загострення конкуренції та змінність умов зовнішнього середовища, посилення кризових тенденцій, що спостерігається сьогодні - всі ці чинники 
обумовлюють необхідність зміни підходів та методів управління підприємством на споживчо орієнтовані. Основним інструментом, що надає можливість підприємству реалізувати споживчо орієнтований підхід, є маркетинг, який забезпечує комунікацію підприємства із основними його стейкхолдерами, насамперед - споживачами. За таких умов раціональна та ефективна організація маркетинг-менеджменту (управління маркетинговою діяльністю) $\epsilon$ вкрай важливим завданням управлінців різних рівнів. Чітке розуміння категоріального апарату, у свою чергу, сприяє підвищенню ефективності управлінських рішень у сфері маркетингу. Перспективи подальших досліджень полягають в ідентифікації основних компонентів системи маркетинг-менеджменту, особливостей іiі формування та використання у практичній діяльності суб’єктів господарювання.

\section{Список використаної літератури:}

1. Гузенко Г.М. Управління та вдосконалення маркетингової діяльності на підприємстві / Г.М. Гузенко // Економіка і суспільство. - 2017. - № 12. - С. 227-234.

2. Іваненко В.О. Маркетингова діяльність як важливий бізнес-процес підприємств-виробників продовольчих товарів / В.О. Іваненко, Л.Й. Юрківська // Проблеми теорії та методології бухгалтерського обліку, контролю і аналізу. - 2015. - Вип. 3 (33). - С. 67-81.

3. Лукан О.М. Економічна сутність маркетингової діяльності підприємства / О.М. Лукан // Економічний простір. - 2014. - № 84. - С. 172-180.

4. Олійник О.В. Маркетинговий потенціал промислових підприємств України / О.В. Олійник, В.О. Іваненко // Вісник ЖДТУ. - 2016. - № 1 (75). - С. 97-103.

5. Павленко I.I. Поняття та суть маркетингу в діяльності підприємств / I.I. Павленко, Т.Ш. Дашевська // Науковий вісник Ужгородського національного університету. - 2015. - № 3. - С. 92-94.

6. Про захист прав споживачів : Закон України від 12.05.1991 р., № 1023-XII [Електронний ресурс]. - Режим доступу : https://zakon.rada.gov.ua/laws/show/1023-12.

7. Шинкаренко В.Г. Етимологія понять «споживач», «покупець» і «клієнт» та їх використання на автотранспортних підприємствах / В.Г. Шинкаренко, І.М. Ананко // Економіка транспортного комплексу. 2012. - Вип. 20. - С. 120-129.

8. Bachmann F. Instruments for the marketing of services and their implementation / F.Bachmann, J.Vaculik [Electronic resource]. - Access mode : http://pernerscontacts.upce.cz/08_2008/Bachmann.pdf.

9. Baimbetova A.A. The principle of effective marketing management / A.A. Baimbetova // Procedia - Social and Behavioral Sciences : 2nd World Conference On Business, Economics And Management 2013. - 2014. - Vol. 109. P. 1322-1325 [Electronic resource]. - Access mode : 10.1016/j.sbspro.2013.12.632.

10. Business Dictionary. - WebFinance Inc. [Electronic resource]. - Access mode : http://www.businessdictionary.com/definition/marketing-tools.html.

11. Blut M. Testing retail marketing-mix effects on patronage: a meta-analysis / M.Blut, C.Teller, A.Floh // Journal of retailing. - 2018. - № 2 (94). - P. 113-135 [Electronic resource]. - Access mode : https://doi.org/10.1016/j.jretai.2018.03.001/.

12. Definitions of Marketing // American Marketing Association [Electronic resource]. - Access mode : https://www.ama.org/the-definition-of-marketing-what-is-marketing

13. Goi C.L. Marketing Mix: A Review of «P»/ C.L. Goi // Journal of Internet Banking and Commerce. - 2005. № 10 (2) [Electronic resource]. - Access mode : http://www.icommercecentral.com/open-access/marketing-mix-areview-of.php?aid=38598.

14. Kotler P. Marketing management / P.Kotler, K.L. Keller. $-14^{\text {th }}$ ed. - New Jersey : Prentice Hall, 2012. -812 p.

15. Tkachenko V. Formation of marketing management system of the enterprise / V.Tkachenko // Baltic Journal of Economic Studies. - 2017. - Vol. 3, № 5. - P. 208-213 [Electronic resource]. - Access mode : http://dx.doi.org/10.30525/2256-0742/2017-3-5-208-213.

\section{References:}

1. Guzenko, G.M. (2017), «Upravlinnja ta vdoskonalennja marketyngovoi' dijal'nosti na pidpryjemstvi», Ekonomika $i$ suspil'stvo, No. 12, pp. 227-234.

2. Ivanenko, V.O. and Jurkivs'ka, L.J. (2015), «Marketyngova dijal'nist' jak vazhlyvyj biznes-proces pidpryjemstvvyrobnykiv prodovol'chyh tovariv», Problemy teorii' ta metodologii' buhgalters'kogo obliku, kontrolju $i$ analizu, No. 3 (33), pp. 67-81.

3. Lukan, O.M. (2014), «Ekonomichna sutnist' marketyngovoi' dijal'nosti pidpryjemstva», Ekonomichnyj prostir, No. 84, pp. 172-180.

4. Olijnyk, O.V. and Ivanenko, V.O. (2016), «Marketyngovyj potencial promyslovyh pidpryjemstv Ukrai'ny», Visnyk ZhDTU, No. 1 (75), pp. 97-103.

5. Pavlenko, I.I. and Dashevs'ka, T.Sh. (2015), «Ponjattja ta sut' marketyngu v dijal'nosti pidpryjemstv», Naukovyj visnyk Uzhgorods'kogo nacional'nogo universytetu, No. 3, pp. 92-94.

6. Verhovna Rada Ukrai'ny (1991), Pro zahyst prav spozhyvachiv, Zakon Ukrai'ny vid 12.05 .1991 r., No. 1023-XII, [Online], available at: https://zakon.rada.gov.ua/laws/show/1023-12

7. Shynkarenko, V.G. and Ananko, I.M. (2012), «Etymologija ponjat' «spozhyvach», «pokupec'» i «klijent» ta i'h vykorystannja na avtotransportnyh pidpryjemstvah», Ekonomika transportnogo kompleksu, No. 20, pp. 120-129. 
8. Bachmann, F. and Vaculík, J. (2008), «Instruments for the marketing of services and their implementation», [Online], available at: http://pernerscontacts.upce.cz/08_2008/Bachmann.pdf

9. Baimbetova, A.A. (2014), «The principle of effective marketing management», Procedia - Social and Behavioral Sciences, 2nd World Conference On Business, Economics And Management 2013, Vol. 109, pp. 1322-1325, [Online], available at: 10.1016/j.sbspro.2013.12.632

10. Business Dictionary, WebFinance Inc., [Online], available at : http://www.businessdictionary.com/definition/marketing-tools.html

11. Blut, M., Teller, C. and Floh, A. (2018), «Testing retail marketing-mix effects on patronage: a meta-analysis», Journal of retailing, No. 2 (94), pp. 113-135, [Online], available at: https://doi.org/10.1016/j.jretai.2018.03.001

12. American Marketing Association, «Definitions of Marketing», [Online], available at: https://www.ama.org/thedefinition-of-marketing-what-is-marketing

13. Goi, C.L. (2005), «Marketing Mix: A Review of 'P'», Journal of Internet Banking and Commerce, No. 10 (2), [Online], available at : http://www.icommercecentral.com/open-access/marketing-mix-a-review-of.php?aid=38598

14. Kotler, P. and Keller, K. (2012), Marketing Management, $14^{\text {th }}$ ed., Prentice Hall, New Jersey, 812 p.

15. Tkachenko, V. (2017), «Formation of marketing management system of the enterprise», Baltic Journal of Economic Studies, Vol. 3, No. 5, pp. 208-213, [Online], available at: http://dx.doi.org/10.30525/2256-0742/2017-3-5-208-213

Орлова Катерина Євгеніївна - кандидат економічних наук, доцент, доцент кафедри менеджменту і підприємництва Державного університету «Житомирська політехніка».

Наукові інтереси:

- у управління бізнесом;

- адаптація підприємств до умов зовнішнього середовища.

https://orcid.org/0000-0002-9985-0210.

E-mail: orlova_ekaterina@ukr.net.

Мельник Тетяна Юріївна - кандидат економічних наук, доцент кафедри цифрової економіки та міжнародних економічних відносин Державного університету «Житомирська політехніка».

Наукові інтереси:

- аналітичне забезпечення системи управління в умовах цифровізації економіки;

- контролювання діяльності підприємства.

http://orcid.org/0000-0002-1743-0264.

E-mail: melnyktanya09@gmail.com.

Стаття надійшла до редакції 22.04.2020. 